\title{
New Thought on Traditional Chinese Industrial Art in Cultural Creative Industry
}

\author{
Lei Sheng \\ School of Art \\ Xuzhou Institute of Technology \\ Xuzhou, China 221008
}

\begin{abstract}
Industrial art is one of important parts of traditional Chinese culture, and it achieves organic combination of art and technique as well as the integration of aesthetics and practicability. In order to create an excellent industrial work of art, we should not only highly value creative design but also pay more attentions to practices. However, both creative design and practices will get involved the relations between art and technique. Facing the situation of cultural creative industry, in order to promote the development and progress of traditional industrial art, it will need talents to support, multi-party to cooperate, brand construction and so on, yet the most basic is innovative drive, based on which, we can really meet the development of cultural creative industry and realize the connection between modern life and industrial art so that the industrial art will be pushed to get healthy and sustainable development in a new area. In this article, this author conducts studies on and simple analysis of new thoughts of traditional Chinese industrial art facing the cultural creative industry, which is expected to push the studies.
\end{abstract}

Keywords-cultural creative industry; traditional Chinese industrial art; innovative thought

\section{INTRODUCTION}

Industrial art is a special form of art, a beautification of living environment where people live and a process of people's living supplies including food, clothing shelter and transportation. During the creation of industrial art, it shall contain the organic combination of technique and art but also include the full integration of industrial operation, sales and creative culture as well as the close relations between intellectual property right and regional characteristics [1]. Cultural creative industry is a new industry in modern society, which regards the support and drive of cultural art and industries, it stresses to take creativity as core and center and culture as theme, as well as individual creativity or team innovation for art process, and finally pushes the development of industrial economy and cultural creative industry, which will promote the market economy in the country. Cultural creative industry has characteristics of higher added value and high integration, the former is mainly reflected on the cultural creative industry which can drive regional economy and relative industries, and the latter is mainly reflected on the cultural creative industry which has characteristics of cross border, cross industry, cross culture, cross nations, cross history and cross language.

\section{TRADITIONAL CHINESE INDUSTRIAL ART}

\section{A. Industrial Art Achieves the Organic Combination of Art and Technique}

Though industrial art values materials and technique, yet it does not mean that the materials and technique are all what the industrial art needs, to judge the value of industrial art works depends on not only the technical complexity but also prices of materials, even whether this artwork can produce a moving effect. The opinion which thinks industrial art is an insignificant skill is improper, because all industrial arts such as puppet, lacquer, ceramics and so on will need technical support[2]. Take pottery as an example, it needs a series of processes such as argil selection, argil screening, mud mixing, blank making, drying and sintering, each of the processes will need special technique as pottery, it needs kneading, mud building, wheel casting, mud cake pasting and so on. In addition, during the pottery making, the pattern design will need comparison between spacing, lengths, curves, static and dynamics, all of which show art. Seen from the points, the industrial art realizes the organic combination between art and technique.

\section{B. Industrial Art Realizes the Integration of Aesthetics and Practicability}

Industrial art has practical value, which has essentia distinction from literature, music, sculpture and drawing that have aesthetic significance. The essential value of industrial art is its practicability; meanwhile, the practicability of industrial art is also needed to support the continuous development of industrial art, which can be thought a physical attribute restricted by materials [3]. In order to survive and work, during the art making, generally the people will adopt materials that are well controllable to which creative images are added so as to form art works. Take ancient industrial art as an example, whether chipped stones or polished ones both underwent repeated technical processes, meanwhile, it also needs to be unceasingly used in practice before getting a tool convenient and endurable, which is the practicability. In addition, in order to make it easy to hold, generally the stones would be chipped to $15-18 \mathrm{~cm}$ long, thin and sharp, in which all functions are included, and the practicability is one of the basic one. Of course, during the stone making, the people formed aesthetic 
consciousness, which was shown as, relying on technical process, the stones not only have physical attributes such as color, shine, hardness, weight, size and so on but also have to some degree aesthetic ideas such as arc, smoothness, balance, symmetry and the like[4]. Seen from above, the industrial art realizes the integration of aesthetics and practicability.

\section{STATUS QUO OF TRADITIONAL INDUSTRIAL ART}

Traditional industrial art is extremely important in traditional Chinese culture, which carries a great number of excellent cultural and artistic expressions. Therefore, in recent years, traditional industrial art has been attracting more and more attentions and valued by authorities, the society and the public. Within the industrial art, paper-cup, Sichuan figured satin and embroidery and brocade are all listed as national intangible cultural heritage, based on such causes, the industrial art has been taken as one of the important parts by the cultural and creative industry during its development. However, seen from current stage, during the development of cultural and creative industry, there are some problems related to the industrial art in the country. It is mainly embodied in the following: First, there is no a complete industrial chain. Currently though the development of cultural and creative industry is being greatly promoted in the country, and the industrial art has attracted more and more attentions and eyeballs, yet the lack of excellent talents has seriously restricted the form, technique, size and growth of industrial art in the cultural and creative industry. [5] Therefore, within the cultural and creative industry, traditional industrial art is not developing well; Second, the industrial art is in the risk of disappearing in current stage, before there are fewer and fewer successors, which cause many industrial art that depend on manual process for inheritance are disappearing. In modern society where individuals and fashions are pursued, many young people think the industrial art is some out of date, unwilling to accept and inherit. Third, pool technical level. For some of traditional industrial arts which have successors, most of the successors are focused on technique, whose manufacturing technique and aesthetic ideas almost have nothing to do with modern elements, it has ultimately caused its separation from modern commercial society; Forth, there are still some who are against the development of industrial art in current stage. Influenced by traditional concepts, some who are rich to some degree in current stage are still thinking industrial art work are collections, so the industrial art works are collected for added value in the future, finally the industrial art is separated from the public and listed in the scope of a few.

\section{NEW THOUGHT CONCERNING TRADITIONAL}

\section{INDUSTRIAL ART IN THE CULTURAL AND CREATIVE INDUSTRY}

Traditional industrial art is an important of traditional Chinese art culture system, and during the development in thousands of years, the industrial art varies with basic necessities of life, which has some real time improvement and innovation. According to the analysis of original jade ware process, it can be seen that the original jade wares have wonderful shape, vivid purpose as well as strict decoration; meanwhile, superb chiseling techniques are used to fully embody the integration of aesthetics and practicability [6].
Scanning the whole development course of traditional industrial art, it has not only cultural characteristics but also local features, with the continuous development of modern production process and technical progress, the field of industrial art also produces a lot of new process design such as commercial art, dyeing art, garment art, technical design of indoor environment and daily industrial product modeling so as to improve the people's aesthetic interest and perfect the living environment. Compared with modeling process as literature, music, sculpture and painting, the industrial art has not only decorative art wares to meet the people's aesthetic requirements but also daily handicrafts to meet the people's material life requirements. The deep digging and continuous exploration on traditional industrial art will not only provide rare opportunities and wide space for the development of cultural creative industry but also find new channels and ways to boost the social and economic development in the country. The new thoughts concerning traditional industrial art in the cultural and creative industry will not only do good to carry forward and protect outstanding traditional culture in the country, but also promote the healthy and continuous development of cultural and creative industry.

\section{THOUGHTS FOR THE DEVELOPMENT OF TRADITIONAL Chinese Industrial ART IN THE CUlTuRAL AND CREATIVE INDUSTRY}

\section{A. Strengthen the Civilization of Professional Talents}

In the cultural and creative industry, in order to enable the traditional industrial art to well survive and achieve a successful transformation and get rapid development, we must strengthen the cultivation of professional talents. Human is a main part during the creation of industrial art, meanwhile, in order to achieve the efficient development of traditional industrial art in the cultural and creative industry, it also needs the layout design of human, which raises requirements on human. Those who perform the work shall not only grasp allsided theoretical knowledge but also own good skills, superb creative design philosophy and innovative thought. For example, scanning the development course of ceramic process in the country, from original ceramics to modern ones, a series of transformation have been completed in the course, transformation from kneading model to wheel process, from carving and chasing to color depiction, from rough ceramics to colored pottery, from celadon to ceramic white-ware and from black pottery to glazed pottery [7]. The difference and changes have not only fully demonstrated the developing energy of ceramic art but also achieved the integration of art and technique, showing the infinite creative ability of human. Based on the above analysis, it needs strengthen the cultivation of professional talents so as to boost the continuous development traditional Chinese industrial art in the cultural and creative industry.

\section{B. Strengthen Cooperation between Departments Concerned}

The protection and development of traditional industrial art in the cultural and creative industry can not be achieved only relying on one department, and it must have policy support of authorities and the promotion from non-governmental 
organization, science and research colleges, industrial associations and so on. Through the cooperation between relevant departments, traditional industrial art can be united with the exhibition industry and tourism industry in order to promote the traditional industrial art to go toward the direction of industrialization.

\section{Strengthen the Brand Construction}

Brand symbolizes the credibility of products concerned, and for consumers, the brand is an important channel for to know the products; the brand stands for the product quality; for enterprises, the brand reflects reputation for products. To strengthen the brand construction is the need of the industrial development and also meeting the development law of market economy. Facing the market economy, if there are no brand enterprises to take the lead, the industry will be lost in downturn. This phenomenon is also reflected in the traditional industrial art[8]. Based on what mentioned above, in order to promote the continuous development of traditional Chinese industrial art in the cultural and creative industry, it is a must to strengthen the brand construction.

\section{Innovation in Art and Technique}

In the cultural and creative industry, in order to make the traditional art have a foothold, stable position, and development, it needs to launch efficient changes in the existing production patterns. However, it must be noted that the changes do not mean to break and throw down the traditions; instead, it is an inheritance and innovation of excellent parts. First of all, seen from the inheritance, we shall not only rescue and protect traditional cultural resources but also strengthen correct understandings of the traditional arts and skills and make them flourish; Second, seen from innovation, we shall not only introduce some new techniques, new processes and new materials to the traditional art, but also follow the trend for creativity and conception, meanwhile, innovation shall be conducted on the operation patterns. In the cultural and creative industry, in order to survive and develop better, traditional Chinese industrial art should follow the trends of the society, meeting the people's lives and responding to the public aesthetics. Only with the premise met to develop industrial market, can traditional industrial art achieve centralized and scaled development and really embody the high value-added features of its own.

\section{CONCLUSION}

In conclusion, the industrial art belongs to the cultural and creative industry, in order to make the traditional Chinese industrial art to get well developed in the cultural and creative industry in the country, we should base ourselves on inheriting traditional art and culture with modern technologies used for improvement and innovation, continue the talents cultivation, strengthen the brand construction and actively explore a development way meeting the times.

\section{REFERENCES}

[1] Zhan Weifeng, New Thought of Putian Traditional Industrial Art in the Cultural and Creative Industry [J].Journal of Ezhou University, 2017,(03):60-62.

[2] Cui Dong, Development and Researches on Traditional Industrial Art on the Basis of Cultural and Creative Industry [J].Studies in Culture \& Art, 2016,(02):10-16.

[3] $\mathrm{Xu}$ Yuanbao, Transformation and Development-Development Trend of Contemporary Traditional Industrial Art in the Cultural and Creative Industry [J]. Sculpture, 2014,(04):64-65.

[4] Shao Wenhong, New Thought of Traditional Chinese Industrial Art in the Cultural and Creative Industry $[\mathrm{J}]$. Journal of Harbin University, 2014,(04):117-120.

[5] Yuan Ling, Positioning and Transformation of Traditional Industrial Art in the Cultural and Creative Industry [J]. Art Panorama, 2013,(08):100.

[6] Tian Zhiyong, Cultural and Creative Industry Raised to State StrategyInterviewing Wang Bin, Director of Foreign Liaison Department of Chinese Arts and Crafts Institute [J]. The Merchandise and Quality, 2011,(37):26.

[7] Huang Huiquan, Cultural Creativity-New Engine for Development of Traditional Industrial Art Industry [J].China Collective Economy, 2011,(02):49-52.

[8] Wang Ning, Transformation of Traditional Chinese Industrial Art in Cultural and Creative Industry [J]. Beauty \& Times (A), 2010,(05):2426. 